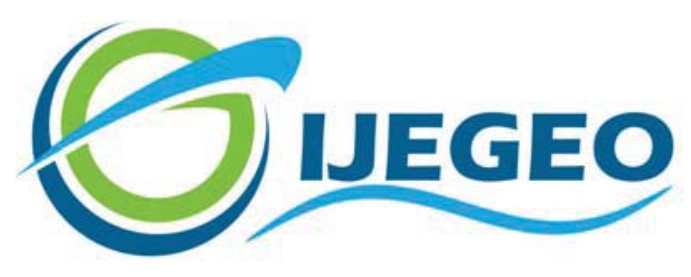

International Journal of Environment and Geoinformatics (IJEGEO) is an international, multidisciplinary, peer reviewed, open access journal.

\title{
Geological and Geospatial Mapping of Vulnerability Areas for Proper Flood Mitigation: Ganaja, Lokoja Metropolis, North- Central Nigeria
}

\section{George Uchebike OZULU, Grace Paul ESSIEN, Ernest Orji AKUDO}

\author{
Chief in Editor \\ Prof. Dr. Cem Gazioğlu \\ Co-Editors \\ Prof. Dr. Dursun Zafer Şeker, Prof. Dr. Şinasi Kaya, \\ Prof. Dr. Ayşegül Tanık and Assist. Prof. Dr. Volkan Demir
}

Editorial Committee (September 2021)

Assoc. Prof. Dr. Abdullah Aksu (TR), Assit. Prof. Dr. Uğur Algancı (TR), Prof. Dr. Bedri Alpar (TR), Assoc. Prof. Dr. Aslı Aslan (US), Prof. Dr. Levent Bat (TR), Prof. Dr. Paul Bates (UK), İrşad Bayırhan (TR), Prof. Dr. Bülent Bayram (TR), Prof. Dr. Luis M. Botana (ES), Prof. Dr. Nuray Çağlar (TR), Prof. Dr. Sukanta Dash (IN), Dr. Soofia T. Elias (UK), Prof. Dr. A. Evren Erginal (TR), Assoc. Prof. Dr. Cüneyt Erenoğlu (TR), Dr. Dieter Fritsch (DE), Prof. Dr. Çiğdem Göksel (TR), Prof.Dr. Lena Halounova (CZ), Prof. Dr. Manik Kalubarme (IN), Dr. Hakan Kaya (TR), Assist. Prof. Dr. Serkan Kükrer (TR), Assoc. Prof. Dr. Maged Marghany (MY), Prof. Dr. Michael Meadows (ZA), Prof. Dr. Nebiye Musaoğlu (TR), Prof. Dr. Masafumi Nakagawa (JP), Prof. Dr. Hasan Özdemir (TR), Prof. Dr. Chryssy Potsiou (GR), Prof. Dr. Erol Sarı (TR), Prof. Dr. Maria Paradiso (IT), Prof. Dr. Petros Patias (GR), Prof. Dr. Elif Sertel (TR), Prof. Dr. Nüket Sivri (TR), Prof. Dr. Füsun Balık Şanlı (TR), Prof. Dr. Uğur Şanlı (TR), Duygu Ülker (TR), Prof. Dr. Seyfettin Taş (TR), Assoc. Prof. Dr. Ömer Suat Taşkın (TR), Assist. Prof. Dr. Tuba Ünsal (TR), Dr. Manousos Valyrakis (UK), Dr. İnese Varna (LV), Dr. Petra Visser (NL), Prof. Dr. Selma Ünlü (TR), Assoc. Prof. Dr. Oral Yağcı (TR), Prof. Dr. Murat Yakar (TR), Assoc. Prof. Dr. İ. Noyan Yılmaz (AU); Assit. Prof. Dr. Sibel Zeki (TR)

Abstracting and Indexing: TR DIZIN, DOAJ, Index Copernicus, OAJI, Scientific Indexing Services, International Scientific Indexing, Journal Factor, Google Scholar, Ulrich's Periodicals Directory, WorldCat, DRJI, ResearchBib, SOBIAD 


\title{
Geological and Geospatial Mapping of Vulnerability Areas for Proper Flood Mitigation: Ganaja, Lokoja Metropolis, North-Central Nigeria
}

\author{
George Uchebike Ozulu,**iD , Grace Paul Essien ${ }^{1}$ (D) , Ernest Orji Akudo \\ ${ }^{1}$ Department of Earth Sciences, College of Natural \& Applied Sciences, Salem University Lokoja, NIGERIA \\ ${ }^{2}$ Department of Geology, Faculty of Science, Federal University Lokoja, NIGERIA \\ * Corresponding author: George Uchebike Ozulu \\ E-mail: george.ozulu@ salemuniversity.edu.ng
}

Received 03 Jan. 2021

Accepted 12 Jan. 2021

How to cite: Ozulu, et al. (2021). Geological and Geospatial Mapping of Vulnerability Areas for Proper Flood Mitigation: Ganaja, Lokoja Metropolis, North-Central Nigeria. International Journal of Environment and Geoinformatics (IJEGEO), 8(3):267-275. doi. 10.30897/ ijegeo. 828668

\begin{abstract}
This study aimed at the geological and geospatial mapping of flood vulnerable areas in Ganaja, Lokoja metropolis for proper flood mitigation. The geological mapping of the study area involved taking several traverses and understudying the different rock types in the study area. Fractures and joint within the rocks show NW-SE, NNE-SSW orientations; corresponding to the predominant stress direction that represent imprints of the Pan-African Orogeny. Buildings within 100 meters buffer distance from the river banks and flood plains are highly vulnerable, those within 200 meters buffer distance is moderately vulnerable while those 300 meters above buffer distance are less vulnerable areas. The relationship between the geology or geomorphology of the area and its effect on flood vulnerability is clearly seen from the geologic, elevation and vulnerability maps of the study area.
\end{abstract}

Keywords: Geologic, Geospatial, Mapping, Vulnerability, Flood, Mitigation

\section{Introduction}

Floods are environmental hazards caused by both natural and anthropogenic factors, although it is generally accepted that rainfall is the dominant cause worldwide (Abowei et al., 2005; Ugoyibo et al., 2017). According to European Commission (2007), a flood can be defined as a natural phenomenon that results in the temporary submerging with water, of a land that does not occur as such under normal natural conditions. It is a natural hazard resulting from extreme meteorological events like heavy rainfall causing rivers and oceans to overflow their banks and can have far-reaching effects on people and the environment (Mohammed, 2018). Flash floods, rapid floods inundating low-lying areas; are the most common in Nigeria during the peak of the rainy season from June to October (Aderoju et al, 2014). Over the years, flooding has become one of the most menacing environmental problems within Lokoja metropolis causing devastating damages to properties and infrastructures and claiming more lives than any other natural phenomena (Nwilo, 2013). This is especially so as over 50 percent of the inhabitants of the area live in the riverside communities including the study area, Ganaja village. This area was heavily flooded, in the peak of the 2012, 2018 and 2020 flood, turning the inhabitants into refugees. According to Onuigbo et al, 2017, the 2012 flood assaulted places like Sarkin-Noma, Gadumo, Kporoko, Jimgbe, Galilee, Kpata, Ganaja village and Saudana areas; all within the Lokoja metropolis. The aftermath of the flood lead to the inundation of farmlands, destruction of farm produce, forced sacking of household, destruction of properties, and ultimately the migration of people leading to scarcity of food.

Flood vulnerability is defined as the probability of flood occurrences and its potential consequences (Alexander $e t$ al, 2011).Vulnerability assessments have been recognized as being crucial to disaster management and are conducted to understand the potentials for loss, focusing on nature of the hazard and who and what are exposed (Enyinnaya, 2015. In the light of this, flood vulnerability mapping is the presentation or representation of areas that are at risk of flood events on maps (Kaoje, 2016). It is very important for an appropriate urban planning to reduce the likelihood of flood occurrence and also reduce the consequences of flood disaster when it happens (Kaoje, 2016).

On the other hand, geospatial analysis is an approach to applying statistical analysis and other analytic techniques to data which has a geographical or spatial aspect. Such analysis would typically employ software capable of rendering maps processing spatial data, and applying analytical methods to terrestrial or geographic datasets, including the use of geographic information systems and geo-informatics (Gonzalez et al, 2012; İncekara et al., 2017 ). In the context of flood hazard management, GIS can be used to create interactive map overlays, which clearly and quickly illustrate which areas of a community are in danger of flooding. Such maps can be used to coordinate mitigation efforts before an event and recovery after the event (Noah, 1999; Awal, 2003). 
Flood vulnerability mapping can provide a means of delineating various areas frequently affected by this phenomenon. Hence, actions can be taken to reduce, prevent and provide solution to this problem. Remote Sensing and Geographical Information System (GIS) are tools which can be used to investigate and map areas that are vulnerable to flooding in conjunction with forecasting techniques. These are to predict the precipitation intensity and duration in a futuristic view (Avşar et al., 2016; Aderoju et al., 2012).

There exist paucity of data and research in area of flood prediction, monitoring and management in Nigeria and especially the study area, hence this research. This study therefore is aimed at assessing areas vulnerable to flooding in Ganaja village using geological and geospatial techniques that will help in the monitoring and managing of subsequent flood disaster occurrence.

\section{Study Area}

The study area Ganaja, is part of Lokoja metropolis located at the confluence of Niger and Benue Rivers and lies between latitude $7^{\circ} 42^{\prime} \mathrm{N}$ and $7^{\circ} 45^{\prime} \mathrm{N}$ and longitude $6^{\circ} 42^{\prime} \mathrm{E}$ and $6^{\circ} 45^{\prime} \mathrm{E}$. It has a total land area of $29833 \mathrm{~km}^{2}$ (Adefisan and Egiku, 2018). Ganaja, like all other suburb of Lokoja metropolis, is noted for two distinct seasons namely: the rainy season and the dry season. The rainy season commences in April and lasts till October, while the dry season is from November to March (Iweana, 2012). The annual rainfall in the area is between $1016 \mathrm{~mm}$ and $1524 \mathrm{~mm}$ while the mean annual humidity is about $70 \%$ (Federal Ministry of Aviation, 2007). A temperature range, between $15^{\circ} \mathrm{C}-40^{\circ} \mathrm{C}$ is usually experienced in the area with an annual average temperature of $33^{\circ} \mathrm{C}$ and an annual average sunshine hour of 6.7/day (Federal Ministry of Aviation, 2007). Temperature during the Hamattan in the night can drop up to $12^{\circ} \mathrm{C}$ between December and January while the

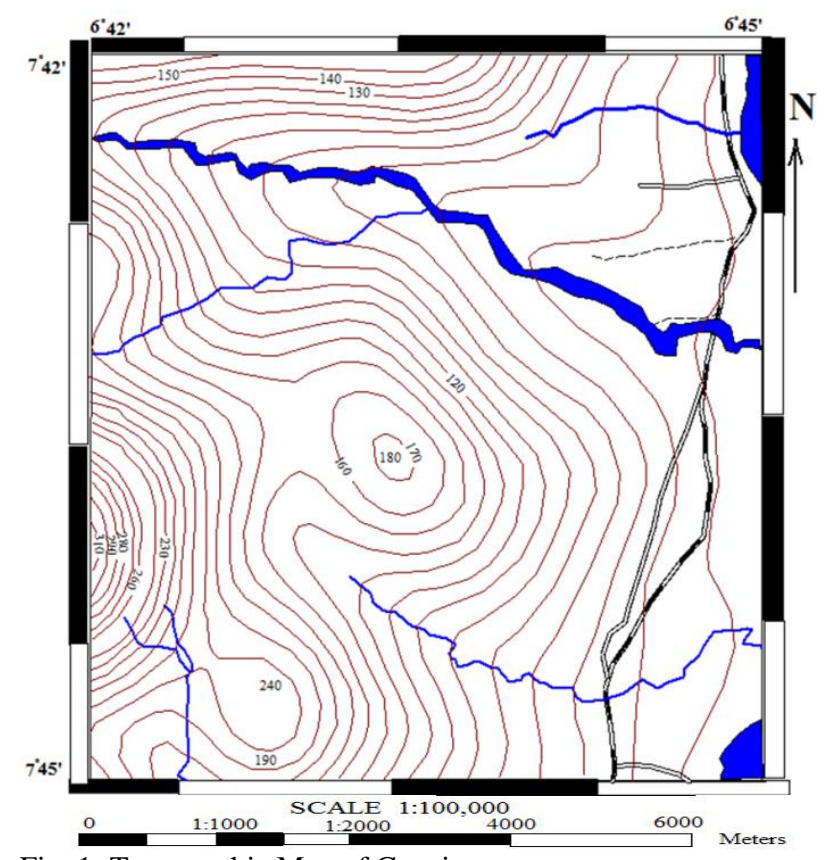

Fig. 1: Topographic Map of Ganaja temperature during the heat period can be as high as $42^{\circ} \mathrm{C}$ between March and April in the day time (Adefisan and Egiku, 2018). The Vegetation of the area is classified as Guinea Savannah type, with denser (gallery) forests fringing some of the rivers (Federal Ministry of Aviation, 2007). The topography of the area is seen to be rugged with an undulating terrain and rock outcrops occurring in several places.

Ganaja village is not only a riverside settlement of low plains but also a hill side settlement. The low lands, which are the flood plains of the Niger River, have been described to have hydromorphic soils containing a mixture of coarse alluvial and colluvial deposits. The alluvial soils along the valleys of the rivers are said to be sandy, while the adjoining laterite soils are deeply weathered, sticky and permeable (Adefisan and Egiku, 2018). During the raining seasoning, water flows down from the hills into the flood plains and at the same time water spills from overbank the Niger River into the flood plains. The excess release of water from Ladgo dam in Cameroon into the River Benue flood plain and similar releases from Kainji, Jebba and Shiroro dams on the Niger River were largely responsible for the 2012 flooding in Nigeria (Adefisan and Egiku, 2018). The partial collapse of the Kainji dam is, however, said to be majorly responsible for the 2020 flooding.

\section{Materials and Methods}

Several materials and equipments were used in carrying out this research. The topographic map of the study area, showing a graphic representation of features such as roads, buildings, hydrographs, relief, vegetation and contours of high and low elevations with respect to sea level' was used as the base map for the geologic mapping (fig. 1).

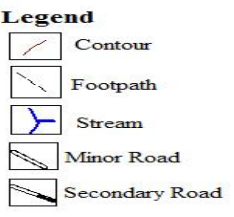


The GPS was used for locating position, sample location and measuring elevation on the field. The Clinometer, an instrument used to measure the angular direction or the attitude of rocks and the structures on the field; was used to measure the inclination (dip), tilt and elevation of rock types.

Three methods were adopted for this work:

(i) Field Geological Mapping

(ii) Laboratory Analysis

(iii) Geospatial Analysis

\section{Field Geological Mapping}

A detailed geologic mapping of the study area was conducted by traversing through to determine the rock types. Careful studies were done at outcrops to observe the geologic features. Geologic mapping of the study area was done to determine the various rock types within the specified coordinates of the topographical map. The structural mapping involved the location and measurement of structures found on the outcrops and rock exposures. These include fractures and joints of the crystalline rocks encountered. Rock types were identified and megascopic studies were carried out in the field.

\section{Laboratory Analysis}

Petrographic analysis was conducted on the rock samples to ascertain the rock types. In preparation for the petrographic analysis, the procedure described by Reed and Mergner (1945) were followed as instructed. After thin-section preparation, the slides were then studied under the Petrographic microscope with respect to Plane Polarized light (PPL) and Cross Polarized light (XPL). The petrographic microscope was used for this study. A total of seven (7) samples from different locations were analysed and their modal composition determined to know the individual mineral constituents for each sample. This was done by finding the percentage of each mineral observed on the microscope, moving the position of the slide at a different count, calculating the number of individual minerals at each count and the percentage of each mineral present from the total number of the minerals.

\section{Geospatial Analysis}

Methodology used for the geospatial analysis entailed three things:

\section{(iv) Data Acquisition \\ (v) Data Entry and \\ (vi) Data Processing}

\section{Data Acquisition}

Data acquisition played an important role as it was the primary operation in this analysis and the software used was ARCGIS. This software, which is a Geographic Information System (GIS) software package developed by the Environmental System Research Institute (ESRI); was used for creating the maps for compiling the geographic data, analyzing mapped information as well as sharing and discovering the geographic information.
This was used to integrate the maps and geographic information in a database. Data acquired for the flood vulnerability mapping and their sources are stated herein: Digital Elevation Model (DEM): The Digital Elevation Model (DEM) is a 3D representation of the land surface elevation with respect to the reference datum. It was used to generate the contour lines in the map of the study area. The digital elevation model used for this work was downloaded from copernicus:

A handheld Global Positioning System (GPS) was used to obtain coordinates within the study area.

(viii) Topographic map of Lokoja S.W. (Sheet 247), comprising the study area, was used to delineate the extent of the study area. This was retrieved from the database of Nigerian Geological Survey Agency (NGSA), Abuja.

(ix) Lokoja image showing features such as built-up areas, facilities, hydrograph, roads etc.; was downloaded from the European Space Agency.

\section{Data Entry}

Data collected from different sources was entered into the ARCGIS software for further processing. The secondary data acquired from European Space Agency containing the digital elevation model was downloaded in a zip format. This was then unzipped using the extract button to enable proper access to the data before transferring it to the software. After this, the remaining data were then transferred directly to the software.

\section{Data Processing}

The appropriate data acquisition procedures involved in arranging and organizing the required manner of data for processing, analysis and presentation were followed at this stage. The steps are presented as follows:

\section{(x) Contour generation from Digital Elevation Model (DEM)}

The Digital Elevation Model (DEM) for the study area (copernicus), a high resolution image of $90 \mathrm{~m}$. This was then used to generate the contours. The DEM was exported to the ARCGIS software and this was further processed using the data management tool on the Arc Tool Box to clip the study area extent on the DEM. As they both have the same coordinate system, (WGS_1984_UTM_Zone_32N), this allowed the imageries to be overlain on each other. The contour analysis on the study area was performed using the contour tool in the raster surface. This was necessary because the DEM and the shape file of the study area are both raster images.

\section{(xi) Query Analysis}

The analysis of the inundated areas was conducted by elevation values via query. This was facilitated by their proximity. The River Niger was extracted from a digitized image of Lokoja data showing several features such as roads, built-up areas, rivers, contours etc. This was done using conditional tool on the spatial analyst. 
The raster was selected in the dialogue box, followed by an expression (Value < 100) on the query box.

\section{(xii) Buffering Analysis}

Buffering analysis, a GIS operation that automatically builds zones with specified width around points, lines or regions geometric objects according to specified buffer distances; was done by selecting the river channels and shape files of the settlement to determine areas that were adversely affected by floods. The Buffering was categorized into various ranges along the affected areas at distances of $0-100 \mathrm{~m}, 100-200 \mathrm{~m}, 200-300 \mathrm{~m}$. These represented zones of high vulnerability, moderate vulnerability, and safe-zone regions of the Study Area. It was done using proximity tool on Analyst toolbox.

\section{(xiii) Desk-Top analysis}

Desk-Top analysis entailed the use of the following softwares for the interpretation of both structural data and geospatial data:

(i) ArcGIS: This is a Geographic Information System (GIS) software package developed by the Environmental System Research Institute (ESRI). ArcGIS version (ESRI, 2013) was used to map the flood vulnerable areas. This helped in creating the maps for compiling the geographic data, analyzing the mapped information as well as sharing and discovering the geographic information. It enabled access to the cartographic and analytical functionalities in the interaction with the geospatial data to produce the maps and diagrams.

(ii) MapInfo Professional: MapInfo Professional version environment was also utilized for map production and cross section drawing. The Geologic map and cross-section of the study area was produced from the integrated topographic map, which formed the base map for this work (Lokoja topographic sheet $247 \mathrm{SW}$ ), using both the ArcGIS and MapInfo environments.

\section{Results and Discussion Geological Mapping}

Seven different rock types encountered during the field mapping exercise include the following:

(i) Porphyritic Granite: This leucocratic, coarsegrained igneous rock has a porphyritic texture. Large conspicuous and prominent crystals (phenocrysts) are embedded in smaller background crystals making up the groundmass.

(ii) Biotite Gneiss: This rock is mostly composed of plagioclase feldspar and quartz, together with some ferromagnesian minerals; the most abundant is biotite. The flakes of mica are seen aligned with their long dimensions' parallel to the mineral banding.

(iii) Migmatite: This mixed rock contains light granitic components and dark metamorphic components. A granuloblastic coarse texture defined by strong foliations of alternating mafic bands of biotite and hornblende; characterizes this rock. (iv) Augen Gneiss: This is a medium to coarse grained, banded, metamorphic rock, composed mainly of quartz and feldspar. Hornblende and mica are also present in variable quantities. Large ovoidal mega-cryst of feldspar grains, known as augen; are quite obvious in the rock.

(v) Banded Gneiss: This metamorphic rock is made up of light and dark coloured minerals that form bands. It has a fine - medium grained texture with highly foliated structure.

(v) Aplitic Granite: This leucocratic igneous rock is fine grained in texture and contains essentially potash and plagioclase feldspars and quartz minerals.

(vi) Medium-grained Granite: This fine-medium grained igneous rock is rich in feldspar and quartz. Minor essential minerals like muscovite, biotite, and amphibole occur as small crystals.

The description of the geology of the study area show biotite and augen gneiss as the dominant rock type in the north - northeast; porphyritic granite and aplitic granite in the centre while migmatite and medium grained granite are dominant in the south (fig. 2). Banded gneiss was only encountered in the central portion of the study area. The study area could be described as an igneous terrain that underwent metamorphism with the regional tectonic episode of the Pan-African orogeny quite evident as imprints of this tectonic event could be seen all over.

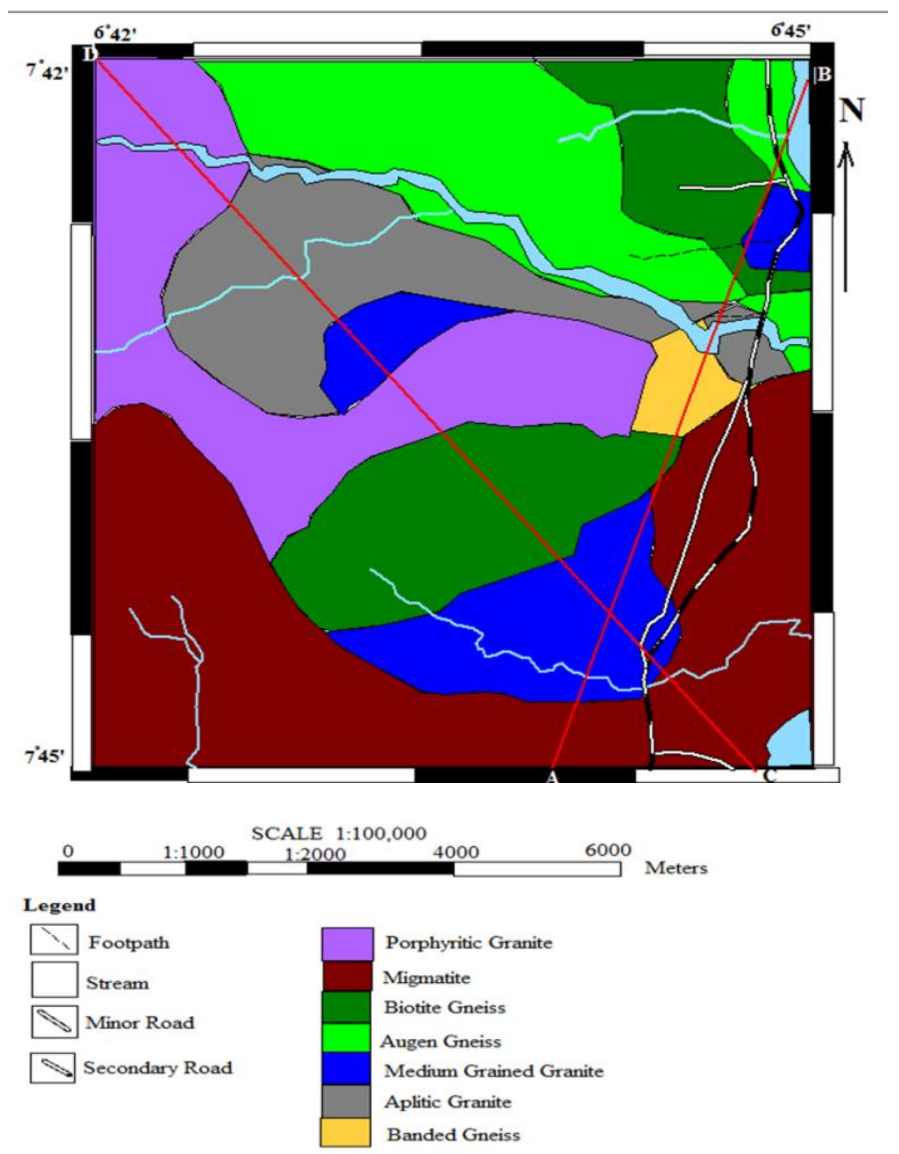

Fig. 2: Geologic Map of the Study Area 


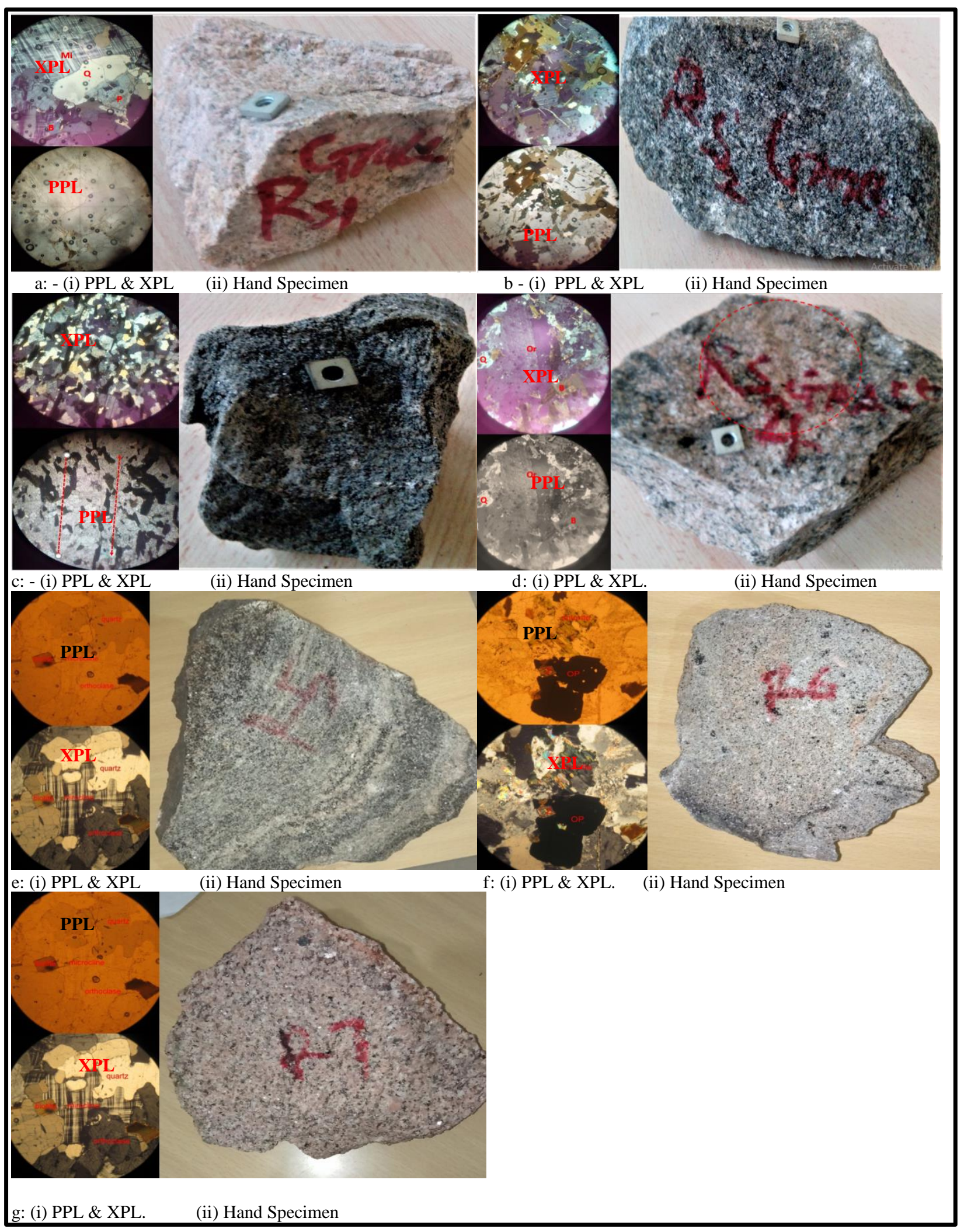

Fig. 3: Photomicrographs of rocks analyzed - (a): Porphyritic Granite, (b): Biotite Gneiss, ( c): Migmatite, (d): Augen Gneiss, (e): Banded Gneiss, (f): Aplitic Granite, (g): Medium-Grained Granite

Results of the petrological analysis are shown in fig. 3. $3 \mathrm{a}$ is leucocratic, coarse grained and porphyritic rock. The phenocrysts consist of microcline and quartz, which are set in a coarse-grained groundmass of muscovite, biotite, quartz, hornblende and plagioclase. The accessory minerals are pyroxene, hornblende, tourmaline, zircon, apatite, topaz. The phenocrysts of microcline range from 2 to $5 \mathrm{~mm}$ long and consist of either a single crystal or mosaic of crystals. They frequently contain inclusions of plagioclase and minor amounts of the accessory minerals. Some of the 
plagioclase inclusions are euhedral and sericitized. The rock has been named Porphyritic Granite.

The quartz observed in $3 b$, under transmitted light; lack cleavage. It has a low relief and is faintly coloured. Biotite minerals which are quite ubiquitous in the rock are recognized by their brown colour and their lack of preferred orientation. They have the highest modal composition in the rock which includes minerals like quartz, biotite, labradorite and hornblende. The rock has been named biotite gneiss.

$3 \mathrm{c}$ is a coarse-grained melanocratic rock with welldeveloped schistose foliation defined by the alignment of laths of biotite with injections of quartz and feldspars. The schistose foliation is defined by the platy mineral, biotite. Other minerals that make up the rock include quartz, microcline and plagioclase. The rock has been named migmatite. $3 \mathrm{~d}$ named augen gneiss has orthoclase phenocrysts showing a combined carlsbad-albite twin pattern; while $3 \mathrm{e}$ banded gneiss, show quartz, biotite and feldspars as the major constituent minerals while accessory minerals include garnet, kyanite and sillimanite.

The aplitic granite, identified in $3 \mathrm{f}$ and medium-grained granite in $3 \mathrm{~g}$; both have the same mineral assemblage of muscovite, biotite, quartz, hornblende and plagioclase. The accessory minerals are pyroxene, hornblende, tourmaline, zircon, apatite, topaz. Muscovites show some level of alteration while feldspars appear to have undergone sericitization.

\section{Structural Geology}

A study of the structural features of the Basement Complex rocks in the area revealed that the orientation of the joints is trending in the NNE- SSW direction while the fractures of the rock is trending in the NW- SE direction, depicting the Pan-African orogenic event. The rosette diagrams show the dominant trend of the geological structures taken during the field observations in various locations.

Table 1: Strike readings of Fractures and Joints within the Study Area

\begin{tabular}{|c|c|c|c|}
\hline $\begin{array}{l}\text { Measured } \\
\text { Values }\end{array}$ & Location 1 & Location 2 & Location 3 \\
\hline $\begin{array}{c}\text { GPS } \\
\text { Reading }\end{array}$ & 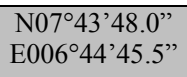 & $\begin{array}{l}\text { N0743'53.9"' } \\
\text { E006 } 44^{\prime} 30.2^{\prime \prime}\end{array}$ & $\begin{array}{l}\text { N07 } 43^{\prime} 59.4^{\prime \prime} \\
\text { E006 } 44^{\prime} 03.4^{\prime \prime}\end{array}$ \\
\hline $\begin{array}{l}\text { Elevation } \\
\text { (m) }\end{array}$ & $\begin{array}{c}\text { Elevation } \\
44.6 \mathrm{~m}\end{array}$ & Elevation $51 \mathrm{~m}$ & $\begin{array}{c}\text { Elevation } \\
50.5 \mathrm{~m}\end{array}$ \\
\hline $\begin{array}{l}\text { Strike of } \\
\text { Fractures } \\
\quad\left({ }^{\circ}\right)\end{array}$ & $\begin{array}{l}126,134,105, \\
78,230,86, \\
110,224,153, \\
260,304,142, \\
242\end{array}$ & $\begin{array}{l}235, \quad 79, \quad 125, \quad 97 \\
140,156,265,209,105 \\
167,120,115,210\end{array}$ & $\begin{array}{l}147,130,95, \\
100,109,87, \\
204,199,183, \\
310,102,189, \\
253\end{array}$ \\
\hline $\begin{array}{l}\text { Strike of } \\
\text { Joints }\left({ }^{\circ}\right)\end{array}$ & $\begin{array}{l}210,98,164, \\
104,128,251, \\
89, \quad 235,207, \\
216\end{array}$ & $\begin{array}{l}160,172,148,310, \\
264,252,208,155, \\
185,234\end{array}$ & $\begin{array}{l}105,167,189, \\
99,210,247, \\
150,175, \\
260,190\end{array}$ \\
\hline
\end{tabular}

\section{Geospatial Analysis}

From the flood vulnerability map (fig. 5), it can be seen that areas less than $100 \mathrm{~m}$ are relatively low and fairly flat. Therefore, it should suffice to say that such areas are highly vulnerable to flooding as run-off from the higher elevation tends to accumulate at the areas of lower elevation and concentration. Similarly, areas greater than $150 \mathrm{~m}$ are less vulnerable to flooding when the river overflows its banks. Considering the elevation variation, the study area is designated to be a lowland area and therefore prone and vulnerable to flood menace. This can be aggravated by the associated poor drainage system in the settlement emanating from poor urban planning and indiscriminate building and waste disposal along flood plains.

Proximity to river channel is an important variable in this study. Buffer distance from the River Niger was categorized from $0-100 \mathrm{~m}, 100-200 \mathrm{~m}$ and 200-300m, with areas within $100 \mathrm{~m}$ of the river categorized as high risk areas. Areas within $200 \mathrm{~m}$ are moderate risk areas while areas located at $300 \mathrm{~m}$ to the river are described as low risk areas as shown in Figs. 5, 6, 7 and 8 respectively.

Findings from similar research on the GIS mapping of flood vulnerability and risk in the Benin Republic (Idelbert, et al,. 2015), asserted that flood vulnerability and risk areas are associated with low elevations close to River Niger. This is in line with the findings of the present research too.

Another important factor to be considered in determining areas vulnerable to flooding is the steepness of the slope. The calculations of the slope angle of the DEM reveals that areas within and without the stream buffer have varying slope angles. Therefore, it is possible that some areas within the river buffer zone are well above water level than the other areas and such areas are said to be less vulnerable to flooding than the latter.

From Figs. 6, 7 and 8 respectively, areas greater than $150 \mathrm{~m}$ (less vulnerable), depicted in green have steep slopes as seen from the contour values while areas less than $100 \mathrm{~m}$ (highly vulnerable) depicted in red have gentle slopes. These areas in red, where you have the settlements built on the flood plains, is vulnerable and susceptible to flooding. Areas vulnerable to flooding have been deduced from the flood vulnerability map (Fig. 5). Similarly, by integrating the geologic map (Fig. 2), elevation map (Fig. 4) and the vulnerability map (Fig. 5); the relationship between the geology or geomorphology of the area and its effect on flood vulnerability can be clearly seen. The western portion of the map has steeper slopes as seen from the contour intervals thereby allowing for easy run-off while the eastern section, flood plains of River Niger, has more gentle slopes with a tendency to accumulate water. 


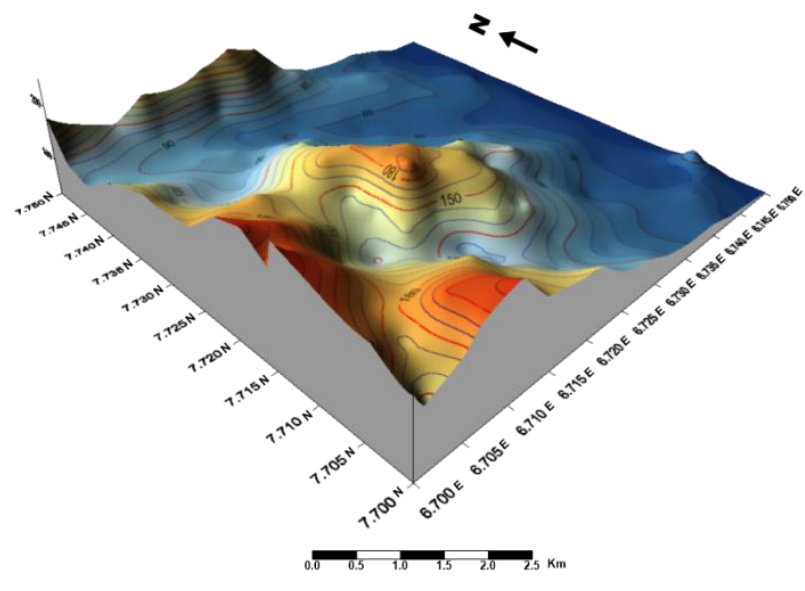

Fig. 4: Elevation Map of the Study Area.

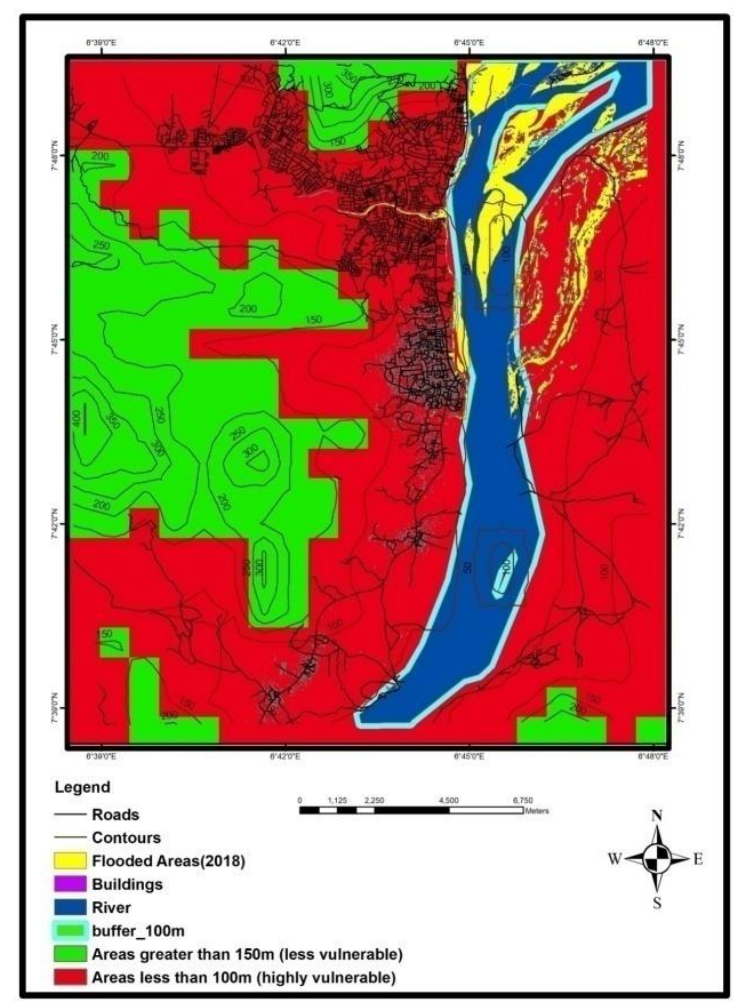

Fig. 6: 100 meters buffer distance from River Niger

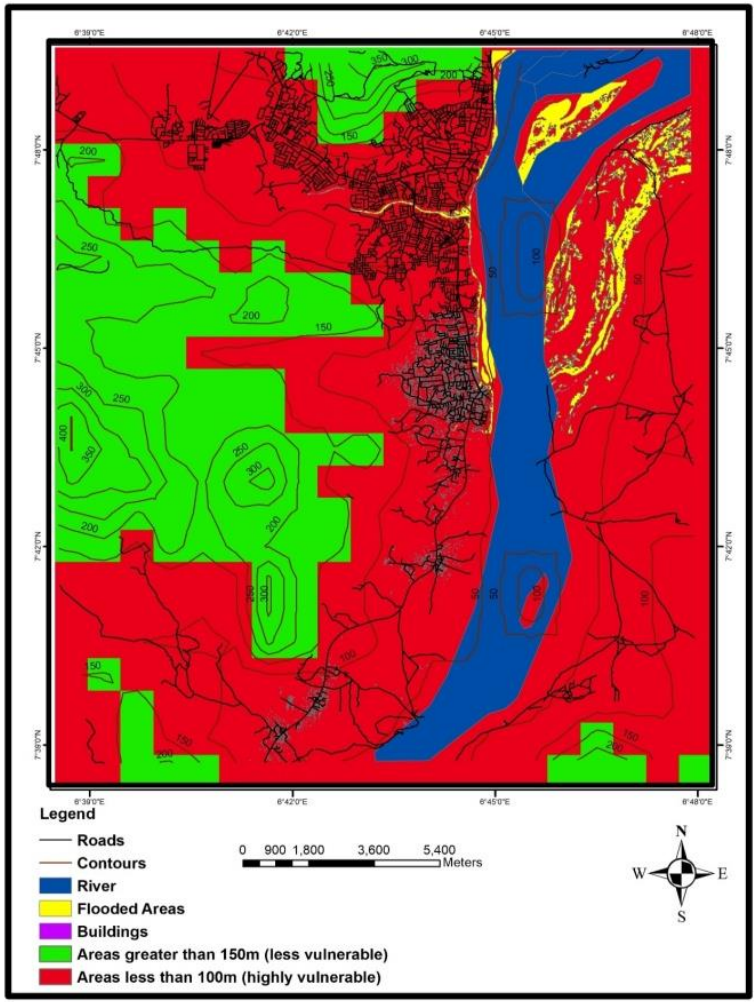

Fig.5: Flood Vulnerability Map of the Study Area

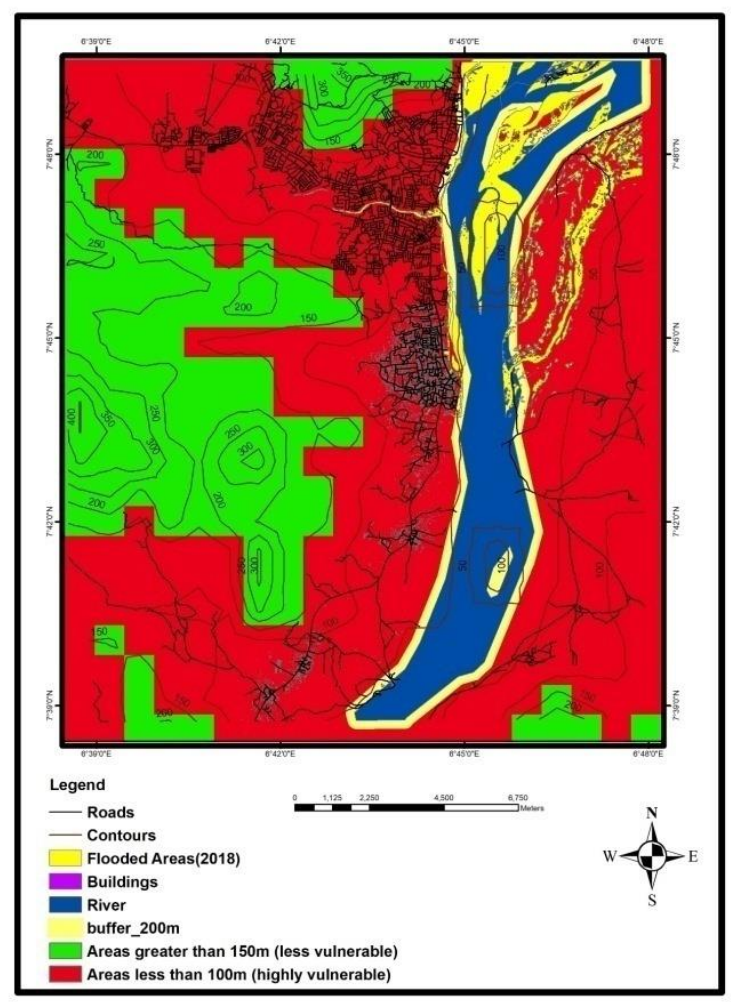

Fig. 7: 200 meters buffer distance from River Niger 
Results of the petrographic analysis, which confirmed the rock types, also show the relationship between the geology of the area to flood vulnerability. The varying types and degree of weathering in the terrain is the direct reflection of the mineralogy and rock types in the study area. The geology of the western portion of the map which experiences easy water run-off is characterized by more resistant rock types as against the less resistant ones in the eastern portion that are more susceptible to intense weathering and therefore flood-prone.

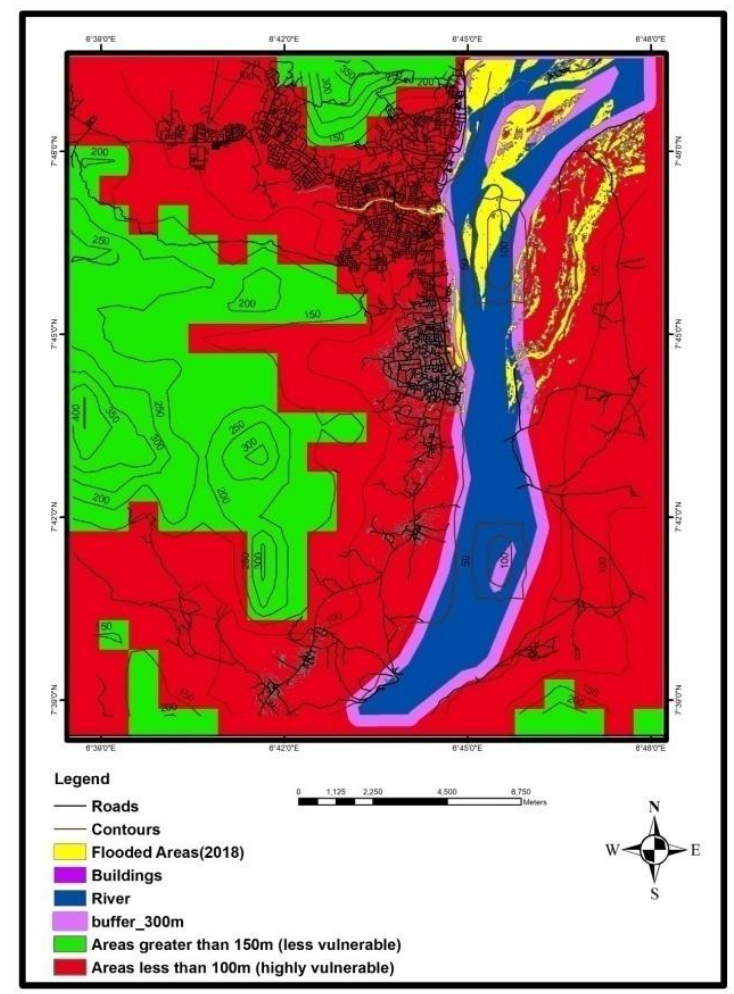

Fig. 8: 300 meters buffer distance from River Niger

\section{Conclusion}

Detailed study of the Geology of the Basement Complex rocks in Ganaja, Lokoja revealed that the dominant rocks in the mapped area are porphyritic granite, aplitic granite, medium grained granite, migmatite, augen gneiss, banded gneiss, and biotite gneiss. Fractures in the area have dominant NW-SE trend directions which correspond to the predominant stress direction that represents the imprints of the Pan-African orogeny while the joints are in the NNE-SSW direction. The flood vulnerable areas were determined through the application of geospatial techniques. The various phases of analysis carried out have given an in-depth understanding of the areas that are vulnerable to flood within the study area.

This study shows that the area is a metamorphic terrain of the south western Basement Complex of Nigeria. Formation of the different rock types in the area is most probably connected to the past tectonic events that affected the area and has greatly influenced the structural and textural features of the rocks.
Geographical Information System and Remote Sensing techniques were adopted in this work in order to map out areas vulnerable to flood. The study has raised awareness on areas that are vulnerable to flood and their magnitudes. The DEM generated and the image drape shows that the study area is not only a river side settlement but also a hill side settlement. This has resulted in increased physical planning problems as buildings are constructed on every available space including the marginal flood plains and river banks thereby causing blockage of river channels and drainage lines leading to floods. This study revealed that areas considered to be less vulnerable are within 200-300m, areas considered to be moderately vulnerable fall within $100-200 \mathrm{~m}$, and areas said to be highly vulnerable are within $0-100 \mathrm{~m}$ from the River Niger bank. The relationship between the geology or geomorphology of the area and its effect on flood vulnerability is clearly seen from the geologic, elevation and vulnerability maps of the study area. The contour intervals in the western section is seen to have steeper slopes thereby allowing for easy run-off while the eastern section, having the flood plains of River Niger; have more gentle slopes with a tendency to accumulate water.

\section{Recommendation}

Based on the findings of this study on flood vulnerable areas in Ganaja, it is recommended that settlements within or adjacent to the areas liable to flooding should be relocated and future settlements should be discouraged. Also, there is a great need for further research on mitigation measures so that the menace of flooding can be minimized in the study area.

\section{Acknowledgements}

The authors are extremely grateful to Salem University Lokoja for the use of their Petrology Laboratory for the petrological analysis and to the Nigerian Geological Survey Agency (NGSA) and National Space Research and Development Agency NASRDA, both in Abuja for providing the softwares for the geospatial analysis.

\section{References}

ACU-Cell, (2003), Bismuth and lithium.

Adefisan, E. A., and Egiku, J., (2018), Vulnerability Assessment of 2015 Flood in North Central Nigeria Using Integrated Approach of Hydrological Model and GIS, Global Scientific Journals (GSJ) 6(8): 262-275

Adeloye, A.J., and Rustum, R., (2011), Flooding and influence of urban planning. Urban Design and Planning, 164 (DP3), 175-187.

Adeoye, N.O. (2012). Spatio-temporal analysis of Land use/cover change of Lokoja- a Confluence town. Journal of Geography and Geology, Canadian Center of Science and education. 4(4), 40-51.

Aderoju, O.M., Jantiku, J., Fagbemiro, O. A., Aliyu, I., Nwadike, B. K., Ajonye, S. E., and Salman, K. S., (2014), Geospatial assessment of 2012 flood disaster in Kogi State. Journal of Environmental Science, Toxicology and Food Technology, 74-84. 
Alexander, M., Viavattene, C., Faulkner, H., and Priest, S., (2011), A GIS-based flood risk assessment tool: supporting flood incident management at the local scale. Flood Hazard Research Centre, Middlesex University, cited in Kaoje, I. U., \&Ishiaku, I., (2017). Urban Flood Vulnerability Mapping of Lagos, Nigeria. MATTER: International Journal of Science and Technology, 3(1), 224 - 236.

Avşar, E., Bozkurtoğlu, E., Aydar, U., Şeker, D., Kaya, Ş., Gazioğlu, C. (2016). Determining Roughness Angle of Limestone Using Optical Laser Scanner. International Journal of Environment and Geoinformatics, 3(3), 57-75, doi.10.30897/ ijegeo.306482.

Awal, R., (2003), Application of Steady and Unsteady Flow Model and GIS for Floodplain Analysis and Risk Mapping. Applied Research by Young Practitioners in South, South East and East Asia, 118-129.

British Geological Survey. (2006), The Physical Properties of Major Aquifer in England and Wales. 97/034, 333.

Dessauvagie Whiteman, A. J., University of Ibadan, 66102.

Enyinnaya, O.C., (2015), Spatial Assessment of Flood Vulnerability in Aba Urban Using Geographic Information System Technology and Rainfall Information. International Journal of Geosciences, 6, 191-200.

European Commission (EC)., (2007), Directive 2007/60/EC of the European Parliament and of the Council of 23 October, on the assessment and management of flood risks, Official Journal of the European Union, L288/27-34.

Gonzalez, A., Donnelly, A., Jones, M., Chrysoulakis, N., and Lopes, N., (2012), A decision support system for sustainable urban metabolism in Europe. Environmental Impact Assessment Review. 38: 109119.

Idelbert, D. B, Michael, T., Joerge, S and Michel, B (2015). GIS based Mapping of Flood Vulnerability and Risk in Benin Niger River Valley. International Journal of Geomatics and Geosciences. 6(3): 1653-1668.

İncekara, A., Şeker, D., Tezcan, C., Bozkurtoglu, E., Gazioğlu, C. (2017). Interpreting Temperature Based Discontinuity and Roughness of Rock Surfaces by Using Photogrammetric Technique. International Journal of Environment and Geoinformatics, 4(3),206-213, doi. 10.30897/ ijegeo.348806.

Iweana, (2012), A Geo-electrical Investigation of Ground Water: 34.

Jeb, D.N., and Aggarwal, S.P., (2008), Flood inundation hazard modeling of the River Kaduna using remote sensing and geographic information systems, Journal of Applied Sciences Research, 4 (12), 1822 $-1833$.

Kaoje, I. U., (2016), Application of Geographical Information System Techniques in Urban Flood Risk Assessment and Vulnerability Mapping. A Case Study of Cardiff, Wales. International
Journal of Scientific and Research Publications 6:2250-3153.

Mc-Curry, P., (1973), Geology of Degree Sheet 21, Zaria Nigeria Overseas Geology and Mineral Resource London; 45

Mc-Curry, P., (1976), The Geology of the Precambrian to lower Paleozoic Rocks of Northern Nigeria, Elizabethan Lagos; 155

Mohammed, A., (2018), Spatio-Temporal analysis of areas vulnerable to flooding in Ibaji local government area, Kogi State, Nigeria, Journal of Resources and Environment, 8(3): 91-98

Municipality, Nigeria. Archives of Applied Science Research, 4 (5):2115-2121.

Nigerian Emergency Management Agency NEMA, (2012), Report on flood disasters in Nigeria. Abuja: Government Press.

Nwilo, P.C., (2013), Geospatial information in flooding and disaster management in Nigeria. 7th Annual Lecture, Faculty of Environmental Sciences, NnamdiAzikiwe University, Awka

Onuigbo, I. C., Ibrahim, P. O., Agada, D.U., Nwose, I. A., and Abimbola, I. I., (2017), Flood Vulnerability Mpping of Lokoja metropolis using Geographical Information System Techniques, Journal of Geosciences and Geomatics, 5 (5), 229-242.

Rahaman, M. A., (1976), Review of the Basement Geology of south western Nigeria in Geology of Nigeria, edited by Kogbe, C.A., Elizabethan Pub. Co, Lagos: 41-58.

Russ, W., (1975), The Geology of parts of Niger, Zaria and Sokoto province, Geol. Survey of Nigeria, 27:42.

Samarasinghea, S. M. J. S., Nandalalb, H. K., Weliwitiyac, D. P., Fowzed, J. S. M., Hazarikad, M. K., and Samarakoond, L., (2010), Application of remote sensing and GIS for flood risk analysis: A case study at Kalu-Ganga River, Sri-Lanka, International Archives of the Photogrammetry, Remote Sensing and Spatial Information Science. 38(B): 110-115.

Suleiman, Y. M., Matazu, M. B., Davids, A. A., and Chioma, M. M., (2014), The Application of Geospatial Techniques in Flood risk and Vulnerability Mapping for Disaster Management at Lokoja, Kogi state, Nigeria, Journal of Environment and Earth Science, 5(4): 45-54.

U.S. Geological Survey, (1998), Retrieved from http://www.usgs.gov/research/gis/title.html on 04/12/2009.

United Nations (UN), (1998), Proceedings of the Seminars on Flood Vulnerability Analysis and on the Principles of Flood Plain Management for Flood Loss Prevention. Bangko.

Van Western, C. J. I., Van Duren, H. M. G., and Terlien, M.T.J., (1993), Training Package for Geographic Information Systems in Slope Instability Zonation. International Institute for Aerospace Survey and Earth Science (ITC), 15 (1): 245. 